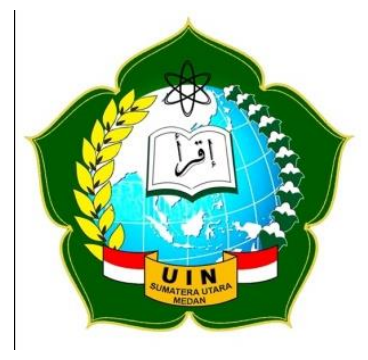

VISION JOURNAL

http://jurnaltarbiyah.uinsu.ac.id/vision

E-ISSN 2745-7982

\title{
The Use of Visual Imagery Strategy to Improve The Students' Writing Skill of Recount Text at The Tenth Grade of Senior High School \\ Siti Andrianti Marpaung
}

Email: siti.andrianti@uinsu.ac.id

Department of English Education, State Islamic University of North Sumatera

\begin{tabular}{|c|c|}
\hline Keywords & Abstract \\
\hline $\begin{array}{l}\text { Keywords: Visual Imagery } \\
\text { Strategy, Writing, Recount Text, } \\
\text { Classroom Action Research }\end{array}$ & $\begin{array}{l}\text { This research was aimed to determine the impact of using } \\
\text { Visual Imagery strategy in enhancing the students' writing } \\
\text { skill. The subjects of this research were the students of class X } \\
\text { MA. Laboratory UIN SU Medan for the } 2020 / 2021 \text { academic } \\
\text { year, which consists of } 40 \text { students. This research was } \\
\text { conducted by doing a classroom action research using two } \\
\text { cycles. Each cycle consists of planning, acting, observing, and } \\
\text { reflecting. The data obtained through quantitative and } \\
\text { qualitative data. The quantitative data were obtained from } \\
\text { tests which included pre-test, post-test I, and post-test II. } \\
\text { Meanwhile, the qualitative data were obtained from } \\
\text { interviews and observation sheets. The results of the data } \\
\text { analysis showed that there was an enhancement on the } \\
\text { students' writing achievements from each cycle. The results } \\
\text { can be seen from the mean score of students in the pre-test } \\
50.85 \text { increased to } 69.4 \text { in the post-test I and increased to } 79.3 \\
\text { in the post-test II. In the pre-test, } 10 \% \text { ( } 4 \text { of } 40 \text { students) } \\
\text { scored }>75 \text {. In the first post-test there were } 55 \% \text { ( } 22 \text { of } 44 \\
\text { students) who scored }>75 \text {. In the second post-test, there were } \\
90 \% \text { ( } 36 \text { of } 40 \text { students) who get a value }>75 \text {. To verify the } \\
\text { hypothesis using the t-test formula, the results of the t-test } \\
\text { obtained t observation ( } 8.60)>t \text { table (1.684). Thus, the } \\
\text { alternative hypothesis (H } \alpha \text { ) can be accepted. Based on these } \\
\text { findings, the alternative hypothesis }(H \alpha) \text { states that the use of } \\
\text { visual imagery strategies can improve students' ability to write } \\
\text { recount text. }\end{array}$ \\
\hline
\end{tabular}

Faculty of Tarbiyah and Teacher Training, 1st Floor

Jalan Willem Iskandar Psr V Medan, 20731

Telp. 061- 6622925 - Fax. 061 - 6615685 


\section{INTRODUCTION}

Nowadays, writing is necessary and needed by people in this modern era. Writing skill is needed in all aspects of the job position. But, most of the students have the lack ability to write in English. Whether they are the words arrangement or grammatically which can be reduced by exercising in the learning and teaching process. Regardless of the language, writing has many rules including grammar, spelling, and punctuation (Utami, 2013). That means, in writing practice consist of the steps and process which can help the students to achieve their goals in writing.

To make a paragraph of recount text, the students must to know basically about the words arrangement and must to know what recount text is. Recount text is a text which consists of the past events or contents but specifically about someone's experiences. It aimed to entertain the readers whether they are a bad or a good experiences. Therefore, an English teacher must use a correct strategy in teaching about writing, especially about recount text.

As the researcher got when the researcher did the teaching training program at the school, the students feel hard to think and put everything from their mind on to the paper. In term, this case related to their imaginations. The students feel confused about what they will to write when the teacher asked to make a paragraph of recount text. They feel difficult to imagine the detail was happened in their mind, and in that situation, the teacher need to give the students a stimulus as a visual to help them imagine the events.

There are some researches related to this strategy, but most of them rarely discussed about writing. The previous researches most combined this strategy with reading comprehension, math, and literature. The result of those researches are visual imagery can affect the learning process. Therefore, the researcher would like to make the new one combination among this strategy and the writing skill of English.

\section{LITERATURE REVIEW}

\section{Recount Text}

As a skill in English, writing has become an important skill for future life because it is needed in various aspects such as science, technology, and others. Writing must become familiar in students' daily lives, because they write to complete many of their learning tasks. According to Sukma (2015), writing exercises can help students to improve their vocabulary and of course improve their ability in grammar. In other words, writing is useful for many purposes. This includes structure, vocabulary, word formation, and other aspects such as spelling, capital letters, and punctuation as well. 
Recount is a text which about the experience of past events (Maureen, 2009) It means, recount text cover all the experiences of the authors in the past time. Whether it was a sad, joyful, even bad experiences. Recount text has the same main ingredients as narrative and are thus very familiar, the difference is that the narrative is imaginative while the recount text has to retell the events that have actually happened (Corbett \& Julia, 2011). Knapp and Watkins (2005) also stated that recounts are sequential text that is nothing more than sequencing a series of events. This is the simplest type of narrative genre.

Recount text differs from narrative text in that the problems are in the sequence of events. Other views emanating from recount could be letters, newspaper reports, conversations, speeches, television interviews, and eye witnesses. Generic structure of recount text according to Hyland (2009), are as follows: a) orientation, b) record of events, and c) re-orientation.

a. Orientation: provides the setting and produces participants. It provides information about who, where, and when.

b. Record of Events, tell what happened, present event in temporal sequence. It is usually recounted in chronological order. Personal comments or evaluative remarks, which are interspersed throughout the record of events.

c. Re-orientation: optional-closure of events. It is rounds off the sequence of events.

\section{Visual Imagery}

Visual imagery strategy is a strategy in which the readers understand a text by analyzing the verbal codes (visual / written language) and nonverbal codes (visual object) in the text (Azkalia, 2018). It means that this strategy expected to the readers to develop the images of the text in their minds. Visual imagery are images that arise due to the power of the visual means. This image tends to bring the reader's image as if they saw the object. For this reason, the students who will practice using visual imagery can easily pour objects that can be visualized.

Meanwhile, according to Damayanti (2013), visual imageries are images that arise by sight. This image provides stimulation to the sense of sight, so that things that are not seen as if seen. Meanwhile, Bartolomeo (2015) stated that visual imagery is the faculty whereby we can 'visualize' an object from memory. Therefore, visual imagery can be called as a strategy which is the human being can used to imagine, to see, everything unseen from memory as if seen. 
Based on some of the definitions stated above, it can be said that visual imagery is anything that can be tasted or experienced through a depiction in memory by a person as if they was seeing or experiencing it in real life.

\section{The Procedures of Using Visual Imagery Strategy}

As the researcher found in https://www.readingrockets.org/strategies/visual_imagery which accessed on 14 September 2020, the following steps are the procedures to apply visual imagery strategy, likely:

1. Listen to the teacher's instruction. The teacher will tell the highlight of the material today and explain it briefly.

2. After that, the teacher will give you a piece of paper which consist of a recount text for each students and the give the students some times for read it.

3. Then the students begin to read. Pause after a few sentences or paragraphs that contain good descriptive information.

4. Share the image you've created in your mind, and talk about which words from the story helped you "draw" your picture. Your picture can relate to the setting, the characters, or the actions.

5. Talk about how these pictures help you understand, what's happening in the story.

6. Continue reading. Pause again and share the new image you created. Then ask the students to share what he sees, hears, tastes, smells and feels. Ask what words helped them create the visual image and emotions. By doing this, you are providing your students with practice with this new skill.

7. All images the students made probably different. Are This is a great time to talk about why your images might be different. Perhaps your child went on a school field trip or had a school assembly that changed the way they created the picture in their mind. Perhaps experiences you've had as an adult influenced what you "drew." These differences are important to understand and respect.

8. Read a longer portion of text and continue the sharing process.

\section{METHOD}

This research uses Classroom Action Research. Classroom Action Research is used because it is intended to improve results for teaching and learning. This helps the teacher to be more aware of the process. Classroom Action Research is described as a cyclist or spiral process which involves the steps of planning, acting, observing and reflecting with each of 
these activities that are systematic and independently carried out and interrelated (Burns, 2009).

In the procedure of data collection, researchers conducts a pre-test. Pre-tests will be carried out before conducting the first cycle to get the situation of teaching and learning in class, information knowledge and student achievement in writing skills especially writing recount texts. In addition, the researcher conducted an unstructured interview with an English teacher and several students, which was conducted to find information about problems that are usually faced by students and English teachers in the class.

The student learning outcomes using visual imagery are analyzed and counted from the number of students who passed the completeness of learning (75). Students' achievement in each cycle is measured by the achievement of their writing products. To find out the average student assessment score given in each treatment, The researcher used four techniques in analyzing the numerical data as follows:

a. To know the means of the students' score in each cycle, the research applied the following formula:

$$
\bar{X}=\frac{\sum x}{\mathrm{~N}}
$$

Where:

$\bar{X}=$ The mean of the students

$\sum x=$ The total of scores

$N=$ The number of students.

b. The researcher sought the students' percentage who passed the CMA score (75) by using formula as follows:

$$
P=\frac{F}{n} \times 100
$$

Where:

$\mathrm{P}=$ the students' percentage

$\mathrm{F}=$ the number of students who passed the CMA

$\mathrm{N}=$ the total number of students

c. To know whether any improvement or not in the students' score, the researcher analyzed their score from pre-test up to post-test score in cycle I and cycle II by using as follows formula: 


$$
P=\frac{y_{1}-y}{y} \times 100
$$

$\mathrm{P}=$ Percentage of the students' improvement

$\mathrm{y}=$ pre-test result

$\mathrm{y}_{1}=$ post-test $\mathrm{I}$

$$
\mathrm{P}=\frac{\mathrm{y}_{2}-\mathrm{y}}{\mathrm{y}} \times 100
$$

$\mathrm{P}=$ Percentage of the students' improvement

$\mathrm{y}=$ pre-test result

$\mathrm{y}_{2}=$ post-test II

d. Then, to know the different of the test success after using visual imagery strategy, the researcher applied the following t-test formula:

$$
t=\frac{\bar{D}}{\sqrt{\frac{\sum D^{2}-\frac{(\Sigma \mathrm{D})^{2}}{N(N-1)}}{N(N)}}}
$$

Where:

$\bar{D}=$ Mean of difference of pre-test and post-test

$\mathrm{D}=$ Difference

$\mathrm{N}=$ Subject of Students

\section{FINDING AND DISCUSSION}

Based on the overall analysis of the meetings, it can be seen that there was a significant improvements from pre-cycle to cycle I and cycle II. The mean of the pre-test 50.85 , it was very low. The mean of the post-test I cycle I was 69.4 , then the average post-test II cycle II was 79.3. It showed that the scores and mean in cycle II are better than the pre-test and post-test I. Students who get a value of $\geq 75$ from the pre-test are 4 students. In the post test I, there were 22 students who scored $\geq 75$. This means that there is an increase from pretest to post-test I. The post-test II of cycle II, students who got point $\geq 75$ were 36 students. It means that most of students were success in writing recount text while 4 students were unsuccessful.

From the qualitative data: interviews and observation sheets, all of this data shows that students give good responses during the online teaching-learning process through the WhatsApp group. From the interview, it was found that students felt interesting in every meeting. From the student observation sheet it can be concluded that students are active and 
respectful during the teaching and learning process. Even though at the first meeting they were a little confused and some of them did not give any response and ignored the researchers' instructions.

However, the next meeting was better than the previous meeting because they were not confused and enjoyed the process. The students were active and enthusiastic in participating in the teaching and learning process. Based on students 'scores and responses in the teaching and learning process, the researcher concluded that the use of visual imagery strategies can improve students' ability to write recount text.

In cycle I, the researcher conducted a pre-test, applied visual imagery strategy and post-test I. Because the results of the mean score of students in the pre-test and post-test 1 were still under the CMA, therefore the cycle II was conducted in order to make students achieve scores above the CMA. The test results will be used as quantitative data.

Before the researcher applies this strategy, the researcher makes preliminary observations and interviews which are used as qualitative data, the researcher also conducts post-observation and interviews to ensure that this strategy is proven to improve students' writing skills. The researchers analyzed qualitative data in order to support the quantitative data. In addition, the researchers used observation sheets to strengthen the data. All of the data showed that students give good responses during the learning process.

In cycle I, students seemed to lack understanding about learning, it was seen from the students' responses. In cycle II students become active in using visual imagery strategy and got the good results. It could be seen from the test results. In the pre-test, only $10 \%$ of students passed the CMA, 55\% in the first post-test, and 90\% in the second post-test. It shows a significant increase of students who pass the CMA (75) where the mean score of students in the pre-test was 50.85, the mean score of students in the post-test I was 69.4. The mean score of students in the post-test II was 79.3.

It represented an increasing in the percentage of the student's mean scores. Apart from using quantitative data, the researchers also use qualitative data to explain the situation in depth. Qualitative data were obtained from interviews and observations which were analyzed using data reduction, data categorization, data presentation, and conclusion drawing. Based on the data analysis, it showed that the increasing in student scores is better and satisfied. Most students are very enthusiastic about learning using this strategy. It got them interested and said it was new to them. Both the results of quantitative and qualitative data indicate that the action and application of visual imagery strategy continuously increase. The following table will be shown the result of t-test. 
Table 1. The t-test

\begin{tabular}{|c|c|c|c|c|c|}
\hline NO & $\begin{array}{l}\text { INITIAL OF } \\
\text { THE STUDENTS }\end{array}$ & $\begin{array}{l}\text { POST-TEST } 1 \\
\text { (CYCLE 1) }\end{array}$ & $\begin{array}{l}\text { POST-TEST } 2 \\
\text { (CYCLE } 2)\end{array}$ & D & $\mathrm{D}^{2}$ \\
\hline 1 & ADL & 82 & 89 & 7 & 49 \\
\hline 2 & AA & 84 & 88 & 4 & 16 \\
\hline 3 & $\overline{\text { ANA }}$ & 75 & 80 & 5 & 25 \\
\hline 4 & $\mathrm{CP}$ & 67 & 76 & 9 & 81 \\
\hline 5 & $\overline{\mathrm{CA}}$ & 75 & 82 & 7 & 49 \\
\hline 6 & DAA & 75 & 77 & 2 & 4 \\
\hline 7 & $\mathrm{DPA}$ & 57 & 77 & 20 & 400 \\
\hline 8 & $\mathrm{DSA}$ & 79 & 90 & 11 & 121 \\
\hline 9 & DRA & 54 & 83 & 29 & 841 \\
\hline 10 & FK & 76 & 89 & 13 & 169 \\
\hline 11 & FA & 64 & 78 & 14 & 196 \\
\hline 12 & FAH & 70 & 79 & 9 & 81 \\
\hline 13 & $\mathrm{FKH}$ & 79 & 83 & 4 & 16 \\
\hline 14 & FR & 47 & 63 & 16 & 256 \\
\hline 15 & HS & 56 & 75 & 19 & 361 \\
\hline 16 & HS & 53 & 71 & 18 & 324 \\
\hline 17 & $\mathrm{JK}$ & 88 & 92 & 4 & 16 \\
\hline 18 & $\mathrm{KS}$ & 80 & 83 & 3 & 9 \\
\hline 19 & MFRV & 75 & 75 & 0 & 0 \\
\hline 20 & MAR & 41 & 60 & 19 & 361 \\
\hline 21 & MAP & 62 & 76 & 14 & 196 \\
\hline 22 & MNS & 62 & 76 & 14 & 196 \\
\hline 23 & NST & 63 & 77 & 14 & 196 \\
\hline 24 & ND & 76 & 88 & 12 & 144 \\
\hline 25 & NDA & 76 & 76 & 0 & 0 \\
\hline 26 & NAT & 78 & 80 & 2 & 4 \\
\hline 27 & $\mathrm{NM}$ & 77 & 78 & 1 & 1 \\
\hline 28 & NAS & 76 & 80 & 4 & 16 \\
\hline
\end{tabular}




\begin{tabular}{|c|c|c|c|c|c|}
\hline 29 & RS & 80 & 83 & 3 & 9 \\
\hline 30 & RS & 56 & 58 & 2 & 4 \\
\hline 31 & $\overline{\text { RAR }}$ & 75 & 90 & 15 & 225 \\
\hline 32 & RAP & 75 & 85 & 10 & 100 \\
\hline 33 & SP & 80 & 85 & 5 & 25 \\
\hline 34 & SDEN & 75 & 80 & 5 & 25 \\
\hline 35 & SA & 60 & 80 & 20 & 400 \\
\hline 36 & SFZ & 65 & 75 & 10 & 100 \\
\hline 37 & SS & 70 & 75 & 5 & 25 \\
\hline 38 & SFD & 65 & 80 & 15 & 225 \\
\hline 39 & TP & 50 & 75 & 25 & 625 \\
\hline 40 & ZAM & 78 & 85 & 7 & 49 \\
\hline & Total & 2776 & 3172 & 396 & 5940 \\
\hline & Rata-Rata & 69,4 & 79,3 & & \\
\hline
\end{tabular}

From the table was:

$$
\overline{\mathrm{D}}=\frac{\sum D}{N}=\frac{396}{40}=9,9
$$

The calculation was done as the formula as follow:

$$
\begin{aligned}
& \mathrm{t}=\frac{\overline{\mathrm{D}}}{\sqrt{\frac{\sum D^{2}-\left(\frac{D}{N}\right)^{2}}{N(N-1)}}} \\
& =\frac{9,9}{\sqrt{\frac{5940-\left(\frac{396}{40}\right)^{2}}{40(40-1)}}} \\
& =\frac{9,9}{\sqrt{\frac{5940-\frac{156816}{40(40-1)}}{40}}} \\
& =\frac{9,9}{\sqrt{\frac{5940-3920,4}{40(39)}}} \\
& =\frac{9,9}{\sqrt{\frac{2019,6}{1560}}}
\end{aligned}
$$




$$
\begin{aligned}
& =\frac{9,9}{\sqrt{1,33}} \\
& =\frac{9,9}{1,15} \\
& =8,60
\end{aligned}
$$

From computation above, it can be seen that the coefficient of $t$ observation $=8,60$. If df $=\mathrm{N}-1=40-1=39$, with the level $\alpha=0.05$ or $5 \%$ and $\mathrm{t}$ table $(1,648)$, so t observation $(8,60)>\mathrm{t}$ table $(1,684)$. Thus, alternative hypothesis $(\mathrm{H} \alpha)$ can be accepted. Based on the finding, the alternative hypothesis $(\mathrm{H} \alpha)$ stating that the use of visual imagery strategy can improve the students' writing recount text.

\section{CONCLUSION}

The conclusion can be drawn based on the result of the test, the students writing skill can be improved by using visual imagery strategy. It can be shown by the students' scores. The mean of pre-test was 50,85 and the students who passed the CMA (criteria minimum of achievement) $10 \%$, the mean of post-test 1 was 69,4 and the students who passed the CMA (criteria minimum of achievement) $55 \%$, and the mean of post-test 2 was 79,3 and the students who passed the CMA (criteria minimum of achievement) $90 \%$. There was an improvement in each cycle. In addition, it also can be seen from the actional hypothesis. Where, $\mathrm{t}$ observation $(8,60)>\mathrm{t}$ table $(1,684)$. Thus, alternative hypothesis $(\mathrm{H} \alpha)$ can be accepted. Based on the findings, the alternative hypothesis $(\mathrm{H} \alpha)$ stating that the use of visual imagery strategy can improve the students' writing recount text. While the qualitative data; interview and observation, the students showed the good responses in the learning process via online through whatsapp group. Those responses showed that using visual imagery can improve the students' writing skill especially in writing recount text.

\section{REFERENCE}

Anne Burns. (2009). Doing Action Research in English Language Teaching, UK: Routledge.

Azkalia, Riyan. (2018). visual imagery strategy as effort tt acquire comprehension. Jurnal Profesi Keguruan 4(2)

Bartolomeo, P. (2015). Visual Imagery. International Encyclopedia of the Social \& Behavioral Sciences, Second Edition (5). 
Damayanti, D. (2013). Buku Pintar Sastra Indonesia; Puisi, Sajak, Syair, Pantun, dan Majas. Yogyakarta: Araska.

Dewi, Utami, (2018), How to Write. Medan: La Tansa Press.

Ken Hyland. (2009). Teaching and Researching Writing. London: Pearson Education Limited.

Knapp, P., Watkins, M. (2005) Genre, Text, Grammar: Technologies for Teaching and Assessing Writing. Sydney: University of New South Wales Press.

Maureen Hyland, (2009). Writing Text Types: A Practical Journal. Australia: R.I.C Publication.

Pie Corbett \& Julia Strong, (2011). Talk For Writing Across the Curicullum. England: Open University Press.

Sukma, D. (2015). A study on writing recount text. Journal of English Education. $1(1)$.

Visual Imagery. From https://www.readingrockets.org/strategies/visual_imagery accessed on 14 September 2020. 